\title{
Relationship between power and knowledge in choosing a cesarean section: women's perspectives
}

\author{
Relações de poder e saber na escolha pela cesárea: perspectiva de puérperas \\ Relaciones de poder y saber al escoger por el parto cesárea: perspectiva de las puérperas
}

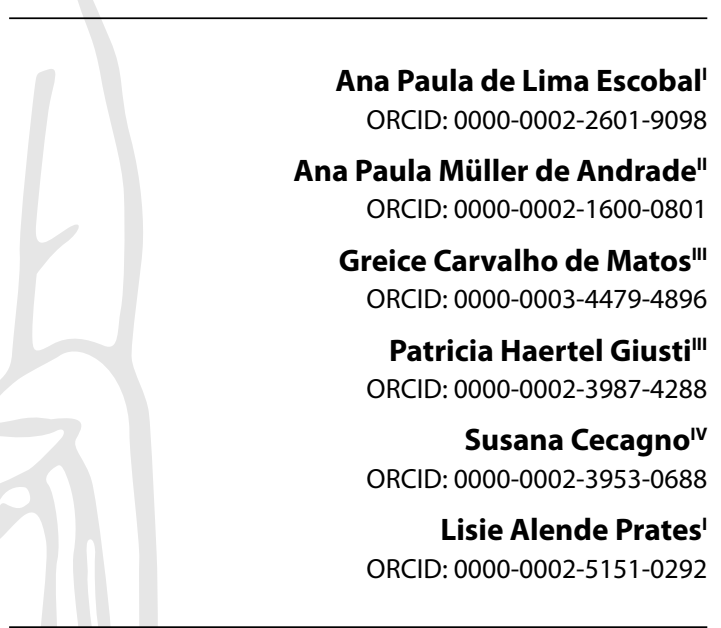

'Universidade Federal do Pampa. Uruguaiana, Rio Grande do Sul, Brazil.

"Universidade Estadual do Centro-Oeste. Irati, Paraná, Brazil.

"'Universidade Católica de Pelotas. Pelotas, Rio Grande do Sul, Brazil.

"Universidade Federal de Pelotas. Pelotas, Rio Grande do Sul, Brazil.

How to cite this article: Escobal APL, Andrade APM, Matos GC, Giusti PH, Cecagno S, Prates LA. Relationship between power and knowledge in choosing a cesarean section: women's perspectives

Rev Bras Enferm. 2022;75(2):e20201389.

https://doi.org/10.1590/0034-7167-2020-1389

Corresponding author:

Ana Paula de Lima Escobal

E-mail: anapaulaescobal@hotmail.com

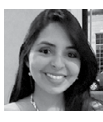

EDITOR IN CHIEF: Antonio José de Almeida Filho ASSOCIATE EDITOR: Fátima Helena Espírito Santo

Approval: 05-11-2021

\section{ABSTRACT}

Objectives: to analyze the reasons and motives that initiates the decision to choose a cesarean section, by describing the plots, power relationships, struggles, and systems of truths regarding this method of childbirth. Methods: a qualitative study, inserted into a poststructuralist perspective, and conducted in a city in southern Rio Grande do Sul state. The settings were a teaching hospital and home residences. Thirteen postpartum women who had a cesarean section participated. The analysis consisted of questions based on the information produced and articulated with Foucauldian theories. Results: two categories were developed: "I wanted a vaginal delivery, but it was a cesarean section", and, "Are you sure you want a vaginal delivery: paths and detours in the choice of cesarean section". Final Considerations: the study allowed us to identify problems in the choice for a cesarean section, which is associated with the circulation of "truths"that occur via discourses on society. Descriptors: Cesarean Section; Physician Patient Relations; Women's Health; Parturition; Obstetrics.

\section{RESUMO}

Objetivos: analisar as razões e motivos que mobilizam a escolha pela cesariana por meio da descrição das tramas, relações de poder, lutas e regimes de verdades sobre essa forma de parir. Métodos: pesquisa qualitativa, inserida na vertente pós-estruturalista e realizada em um município do sul do Rio Grande do Sul. Teve como cenários um hospital de ensino e os domicílios. Participaram 13 puérperas que realizaram cesariana. A análise se constituiu de questões elaboradas diante das informações produzidas e articuladas com as teorizações foucaultianas. Resultados: foram elaboradas duas categorias: Eu queria parto vaginal, mas foi cesárea, e Tu tens certeza que queres parto normal?: caminhos e descaminhos na escolha pela cesariana. Considerações Finais: o estudo permitiu problematizar que a escolha pela cesariana está veiculada à circulação de "verdades", que acontecem por meio de discursos na sociedade. Descritores: Cesárea; Relações Médico-Paciente; Saúde da Mulher; Parto; Obstetrícia.

\section{RESUMEN}

Objetivos: analizar las razones y motivos que llevaron a escoger el parto cesáreo, utilizando la descripción de tramas, relaciones de poder, luchas y régimen de verdades sobre esa forma de parir. Métodos: investigación cualitativa, incluida en la vertiente postestructuralista y realizada en un municipio del sur de Rio Grande do Sul. Tuvo como escenarios, un hospital docente y los domicilios. Participaron 13 puérperas sometidas a parto cesárea. El análisis, fue construido por preguntas elaboradas frente a las informaciones producidas y articuladas con las teorías Foucaultianas. Resultados: fueron elaboradas dos categorías: ¿yo quería parto vaginal, pero fue cesaría y tú tienes seguridad que quieres parto normal?: trayectoria y obstáculos para decidir por el parto cesárea. Consideraciones Finales: el estudio permitió problematizar que escoger la cesaría está condicionada a un círculo de "verdades", que ocurren por medio de discursos en la sociedad.

Descriptores: Cesárea; Relaciones Médico-Paciente; Salud de la Mujer; Parto; Obstetricia. 


\section{INTRODUCTION}

Before the $19^{\text {th }}$ century, the practices related to delivery were envisioned from the perspective of femininity, because it was an event that happened among women. In response to scientific improvement, the questions related to childbirth became part of the field of medicine and, to respond to the needs of the time, this event began to be considered from the pathological perspective, which required interventions, medicalization and invasive procedures. Therefore, cesarean section began to be considered within the society as a possible birth route, considering that advances in anesthetic, surgical, and blood product techniques made the procedure safer over the years ${ }^{(1)}$.

However, the high rates of cesarean section have provoked numerous debates about the factors that mobilize the choice for this mode of birth in contemporary society, as well as about the way this hegemonic modality of birth was established in certain countries, especially in the Brazilian reality. Thus, it is necessary to emphasize that studies and research show that cesarean section, when performed routinely, can lead to a range of complications for the mother and baby ${ }^{(2-3)}$.

The literature points out that the choice of cesarean section involves a number of factors, including family issues, fear of pain, fear of complications for the baby and media influence when relating vaginal delivery to suffering and, above all, the indication of the obstetrician. Another aspect inherent to the choice of cesarean section is related to the scarcity of dialogue between pregnant women and health professionals during pregnancy about the real indications of cesarean section, a fact that contributes to the fear of delivery and the desire for the surgical route ${ }^{(4-5)}$.

It is noteworthy that, in some situations, when women start prenatal care, they prefer vaginal delivery, however, as the consultations progress, they end up changing their choice for cesarean section, adhering to the discourse often given by the obstetrician ${ }^{(6-7)}$. In view of this, it is possible to see that, although the woman often has the desire to perform vaginal delivery and presents information and knowledge about this route of birth, the choice of the obstetrician for cesarean section prevails, since in this context they are permeated power relations ${ }^{(8)}$.

Power relationships are anchored in certain fields of knowledge, which occur through discourses, determining what can be thought and how it will be, what can be said and how it should be said in each historical epoch ${ }^{(9)}$. In this sense, in many situations, at the moment of choosing a birth route, women are submitted to the actions established and prescribed by obstetricians about their bodies and behavior, as they are in a relationship of power associated to biomedical knowledge. This article reports the results of a dissertation, with the following guiding question: "How is the relationship between knowledge and power expressed when choosing cesarean section?".

\section{OBJECTIVES}

To analyze the reasons and motives that initiate the choice of a cesarean section by describing the plots, power relationships, struggles, and systems of truths regarding this method of childbirth.

\section{METHODS}

\section{Ethical aspects}

The research met the ethical principles of Resolution n. 466/2012 of the National Health Council, Ministry of Health $(\mathrm{MOH})$, and the Code of Ethics of Nursing Professionals ${ }^{(10)}$. The study was approved on January 15, 2017, by the Research Ethics Committee of the Federal University of Pelotas. The participation of postpartum women was voluntary after signing the Informed Consent forms, ensuring the confidentiality and anonymity of the participants. The postpartum women were identified by the term Postpartum woman, followed by the numerical order of the interviews (Postpartum woman 1; Postpartum woman 2; Postpartum woman 3, and so on, successively).

\section{Type of study}

This was a qualitative research study, within the poststructuralist perspective. Studies in this aspect cover the way of questioning, problematizing questions and constructing and list research questions. To do so, it is necessary to depart from what is established, from truths, convictions, universality and from the task of prescribing. However, having the freedom to develop this way of research does not mean lack of rigor. In this sense, the aspect proposed in the study considers the subject in the constitution phase, change and subjected to the conditions present in contemporaneity, that is, with a modifiable character, as the truths that are presented in its historical time ${ }^{(11)}$. In addition, the Standards for Reporting Qualitative Research $(\mathrm{SRQR})^{(12)}$, from the EQUATOR network ${ }^{(13)}$, was used to guide the writing of this article.

\section{Study Setting}

This study was conducted in a city in the south of Rio Grande do Sul, and had a teaching hospital and the postpartum women's households as spaces for the production of information.

\section{Data source}

The participants were 13 postpartum women who met the following inclusion criteria: had undergone a cesarean section at the gynecological and obstetric clinic of the hospital and older than 18 years of age. Mothers who had stillbirths were excluded. The number of women in this study was determined according to the data saturation criterion, which consists in interrupting the recruitment of new participants when a recurrence of information is achieved ${ }^{(14)}$.

\section{Data collection}

Data were collected by the main researcher, using the indepth interview technique, between March and May 2017. The technique used in data collection predicts that the interviewer develops a degree of proximity and intimacy with the study participant, which allows highlighting, with rich detail, important facts and transcendent to the context of his/her experience ${ }^{(15)}$. The researcher was prepared on the technique of data collection 
and pilot test before the data collection. The guiding question used in the interview was: "Please describe your experience with the process of choosing and performing the delivery".

The invitation to the participants was made after the first 24 hours after the baby's birth. The researcher had no previous contact with the maternity hospital or the postpartum women who participated in the study. Some mothers preferred to be interviewed at the hospital, in a room in the maternity ward or in their own room, when private, in order to preserve confidentiality. For those who chose to be interviewed at home, the day and time were scheduled. Then, the participant was interviewed individually in a private room of the house. No refusal was reported as all the invited women agreed to participate in the research

The interviews were audio-recorded and, after transcription, were stored in a single file, with an average duration of one hour. The analysis of the empirical material was based on the guidelines suggested in poststructuralist research, with reading of the information produced, followed by weightings based on these questions. From this perspective, we chose to avoid the following type of question: why did you choose cesarean section? We focused on questioning: how did the discourses regarding the choice of a cesarean section occur? How are the power and knowledge relationships established in choosing a cesarean section? The mapping of these questions was constituted on a table, based on the similarity of the ideas present in the excerpts of the interviews. Next, the interpretation of the data was described and articulated with the concepts of power, knowledge and discourse relations ${ }^{(11)}$, which allowed the elaboration of two analytical categories: "I wanted a vaginal delivery, but it was a cesarean section", and, "Are you sure you want a vaginal delivery? Right and wrong turns in the choice of cesarean section", which will be presented below.

\section{RESULTS}

Thirteen mothers, between 20 and 41 years, participated in the research. Six of them had complete high school education, five completed secondary school, and two had incomplete secondary school education. All of them underwent prenatal care. The number of visits ranged from eight to 13. Regarding hospitalization, six mothers were treated in the private system, and seven mothers in the Unified Health System (UHS).

\section{I wanted a vaginal delivery, but it was a cesarean section}

The present category was composed of excerpts from the interviews of postpartum women who underwent cesarean section, with vaginal delivery as the initial choice. Nine women interviewed stated that they had chosen vaginal delivery at the beginning of prenatal care; however, due to some circumstances, such as physiological changes, family organization, and the obstetrician's decision, they changed this choice during pregnancy. According to the reports, the women chose vaginal delivery, understanding that it would provide greater autonomy.

I have read a lot of things about childbirth. When I started to think about getting pregnant and having my child, I read a lot about normal birth, humanized childbirth, the post-section period and also letting a child be born when he or she is ready, you know? Nature. I wanted to be part of it. I wanted to be the protagonist. I wanted to have my child. I wanted to hold him when he was delivered, I wanted to do it, I wanted to empower myself. I read many things about empowerment, [...]. I chose [name of obstetrician] by recommendation of a co-worker who had a child and she said she was an advocate of normal childbirth and I wanted normal childbirth, l always wanted it from the beginning. (Postpartum woman 01)

I did the prenatal care with another obstetrician who was not my gynecologist, but as we had a health insurance plan, I chose another obstetrician. I always told her that I wanted a vaginal delivery, because I always wanted one and I had a very bad experience in the other post-op period [previous ectopic pregnancy]. I told her from the beginning: "look, I want a vaginal delivery!". (Postpartum woman 10)

The preference for vaginal delivery was also related to previous experience with the birth of the first child. They also mentioned the benefits of recovery from vaginal delivery compared to a cesarean section, would favor a faster return to activities.

I wanted to have a vaginal delivery because my first daughter was born vaginally; she stayed until the last day. I felt much better, because a normal birth is painful at the time, but afterwards the recovery is much faster. The rehabilitation is much better in a natural birth, and in the next day you can eat better, walk better. It is not like in a cesarean section. In a cesarean section, you always feel the pain. It is much more painful. [...] Everything was already agreed with my obstetrician, that it would be a vaginal delivery. (Postpartum Woman 02)

The delivery of my other son was vaginal, and it was veryeasy. He suckled soon after he was born. My rehabilitation was very fast. This made me really want to have a vaginal birth again. I have another child at home and then I would already need to take care of things around the house. Plus, there are all the benefits of vaginal birth for the child. (Postpartum woman 03)

I had already had a c-section in my last pregnancy, and as I am chubby I had a hard time recovering, my healing was difficult, not to mention the pain. I really wanted a vaginal birth in this pregnancy, I had read and participated in blogs on the internet about the benefits of vaginal birth for the mother and her baby. So, for me the best thing was the vaginal birth. (Postpartum woman 05)

Whenever I thought about getting pregnant, from the beginning I always wanted a vaginal delivery, because it hurts less, the recovery is faster. As the birth of my first daughter was cesarean, I suffered a lot with the recovery, in addition to the difficulty to breastfeed. But I would not insist on something that could harm my child, as in the previous pregnancy I was not dilated. (Postpartum woman 13)

For one of the postpartum women interviewed, the choice for vaginal delivery was linked to the fact that she had HIV virus. She mentions that she received medical advice about this possibility and, from then on, she started wanting this birth route.

I always wanted to have a normal delivery, because it is better for mother and baby, and I was HIV positive. I thought it would not be possible, but the physician told me that I could have a vaginal 
delivery because I was "undetectable". They told me that they would induce my labor. The physician was the one who explained all of this to me. I knew that because I was HIV positive, I could not breastfeed my child. So, I wanted the opportunity to have a natural delivery so that I could participate in his birth, feel closer, since I wouldn't be able to breastfeed. (Postpartum woman 06)

This participant had absolute contraindications to breastfeeding, which implied the desire for vaginal delivery because she considered that it would allow greater proximity and bonding with the baby. She also visualized childbirth as her best form of autonomy in the trajectory of birth.

\section{Are you sure you want a normal delivery?: right and wrong turns in the choice of cesarean section}

The following excerpts are fragments of interviews with postpartum women about the situations that caused them to change their minds about the route of birth during prenatal follow-up. It is also possible to visualize the paths that distanced them from vaginal delivery and brought them closer to the cesarean section. The strong, hegemonic influence of the obstetrician in this change has to be highlighted, as well as other situations that contributed to the cesarean section outcome.

When I showed my glycemic control levels to her [obstetrician], she was already preparing me: "look, you have a great chance of having a C-section. I knowyou want a normal birth, butyou need to understand that this tends to get worse during pregnancy, you have to prepare yourself, you have to keep an open mind so that your child can be born in the best possible way". Even so, I was prepared and thought I would be able to have a vaginal delivery. (Postpartum woman 01)

There is resistance! I noticed some resistance for various reasons: "look, your baby is big", "look, there is this issue of myoma [the woman had a myoma during her pregnancy], are you sure you want a vaginal delivery? [obstetrician's question]". But I insisted until the last moment. (Postpartum woman 10)

I told the obstetrician that I preferred a vaginal delivery, because my other child's birth was vaginal, but in my first consultation my gynecologist told me it would be a cesarean section, because of my age, so that I would not force myself. She made it very clear from the first appointment that my delivery would be by C-section and that they would take it before 39 or 40 weeks. (Postpartum woman 03)

I had no preference for vaginal delivery, because I have a sevenyear-old daughter at school age who needs my attention, but in my first consultation my gynecologist told me it would be a cesarean section, because of my diabetes, due to the risk of bleeding, and she made it very clear from the first appointment that it would be a cesarean section and that it would be done before 39 or 40 weeks. (Postpartum woman 09)

The fragments of the interviews with the postpartum women allow detecting an obstetrician's direction during prenatal care for the modification of the decision of the postpartum women by the way of birth. The excerpts described above are from the interviews with women who had prenatal care in the supplementary system.
However, as shown in the following statement, for women who had a cesarean section in the UHS, the change of the birth route was made without explanation. It is still necessary to highlight that, in other situations, this change was decided by the obstetrician, within or outside of the UHS.

To be honest, I was in so much pain that I did not think anything of it at the time. It is like this: you are a physician, it is your choice, is it right to do a C-section? So, let us do a C-section. If it is, if you have to do a C-section for my daughter to be born well, I honestly forgot to ask my sister why she did not also tell them that I could have a normal birth. But I didn't even realize at the time to tell them that I wanted a vaginal delivery, you know? Because when you are in pain, you forget everything, you do not worry about whether it will be a vaginal delivery or a cesarean section, and you just want your child to be born, immediately. (Postpartum woman 06)

During the prenatal period, the nurse at the clinic said that I had enough conditions for a vaginal delivery. I arrived at the hospital with contractions, around $8 \mathrm{pm}$, the membranes had already ruptured, and at midnight, they announced that I had to have a cesarean section because I was not dilated enough. I even asked if I could not wait, because I wanted vaginal birth, but they said that the baby could go into distress. (Postpartum woman 08)

Apparently, not having a vaginal delivery seems to generate frustration in some women. The participants demonstrated that they created expectations about this experience and that they idealized the performance of vaginal delivery and a closer relationship with the newborn. Another participant also mentioned that she did not question the possibility of having a vaginal delivery, delegating control of the situation to the obstetrician.

I wanted to have my son. I wanted to hold him, when he came out. I wanted to do it. When he was born, they put him on top of me, but quickly, because I was feeling bad from the anesthesia and it seemed that I was going to vomit over him, and I did not want to throw up over him. I asked them to take him out, and then I never saw him again, only later, when I went to the room. (Postpartum woman 01)

It was frustrating, very frustrating, because I planned this throughout my pregnancy and I always talked a lot about the delivery, because most people here in our country have cesarean sections without any indication. Then, we realized that it could be avoided, because it is a surgery. To get an idea, it was scheduled two weeks ago [before the interview, which was done right after birth]. (Postpartum woman 10)

Honestly, just yesterday l asked a physician why I had a cesarean section, because I wanted a vaginal delivery, and they did not ask me if I wanted a vaginal delivery or a cesarean section. I arrived here with pain and the only thing they told me was that they gave priority to those who were HIV positive. They did a Csection, because I was HIV positive, that is all, and then I went to the surgical center. That was it. They did not ask me if I wanted a cesarean section, if I wanted a vaginal delivery, they did not ask me anything. (Postpartum woman 06)

From the postpartum woman's report, it is possible to infer that, even if she presented knowledge that her viral load was undetectable, at the time of delivery, factors such as anxiety, 
fear, anguish and concern for the baby's well-being, she corroborated that no questions were asked about the possibility of vaginal delivery and, thus, obstetricians chose the route of birth. According to her, the health team involved in childbirth did not clarify why she underwent cesarean section.

Moreover, as can be seen in the reports, there is attribution of responsibility to women, in case of any intercurrence with the child during the delivery chosen by them. Thus, they delegate to the health professional the decision on the route of birth.

The physician was the one who chose my delivery way. If she had supported me and said, "come on, let's try until the end and if everything goes wrong we'll try a cesarean section". No, she said: "your baby is big", always questioning me whether I was sure of a vaginal delivery. So, this influences your decision. If there was not the issue of the myoma or just the fact that the baby was big, I would have gone through with it, but l even told my mother that she had begun to talk about a cesarean section. I did not want to challenge her and risk it, because I was insecure. If I were sure, I would have tried a vaginal delivery. (Postpartum woman 10)

I believe that when you make a decision together with the physician, you are being influenced by him, because in fact, he is the one who has the knowledge, because even though I am a healthcare professional, and understand a little, for example, I know the biochemistry of gestational diabetes mellitus, I know that it can cause several problems, but even so, I think that the person who is the gynecologist has confidence in him. (Postpartum woman 01)

I did not question at any time. Ah, because I want a vaginal delivery! If a C-section is necessary, it will be, because the physician knows what is better, right? The endocrinologist who was following me up also said, look, it has to be a cesarean section, I do not advise a vaginal delivery. I am 41 years old, and it is my first pregnancy, I really wanted a vaginal delivery, but I trust the medical professionals. (Postpartum woman 09)

The postpartum women stated the lack of support from health professionals regarding the mother's decision, associated with the woman's insecurity about whether or not a cesarean section is necessary. Also, the woman's trust and power over her own body is subordinated to the physician.

\section{DISCUSSION}

The experience of vaginal delivery, when anchored by respect and safety, can enable women a differentiated existential experience, generating a sense of competence as a mother and person. In addition, it can provoke positive affective memories related to motherhood and physical and emotional well-being for being free from the painful sensation caused by the surgical wound ${ }^{(5)}$.

Regarding cesarean section, the literature indicates that, when well indicated, it promotes benefits to the mother and newborn, especially in the prevention of neonatal sequelae. However, the realization of this practice without well-defined criteria carries additional risks. Like every surgical process, cesarean section may present anesthetic complications, surgical accidents and transfusion reactions ${ }^{(16)}$.

According to the postpartum women interviewed, the initial choice for vaginal delivery was produced and strengthened by readings, family experience, and the search for bodily selfknowledge. However, even though women had a desire for vaginal delivery, the medical discourse linked to cesarean section proved to be hegemonic among obstetricians in deciding the route of birth.

The previous experience of the postpartum women interviewed with vaginal delivery was also a determining factor in the choice of birth route. Another aspect pointed out was the understanding that vaginal delivery would enable a faster recovery and help the puerperal woman in self-care and care for the newborn. This perception was increased in situations in which the puerperal women needed to combine care with other children and household activities, being difficult to comply with the necessary rest in the postoperative period of cesarean section. In this direction, the study that sought to know the influences of women in the choice of vaginal delivery revealed that they had opted for this way of birth due to the possibility of greater autonomy, and faster return to daily activities ${ }^{(17)}$.

Although some postpartum women have relied on a certain area of knowledge and personal and/or family experiences to choose vaginal birth, a hierarchy has marked the power relations between them and obstetricians, which has often led to the final decision being made by medical professionals. Therefore, nowadays, although the pregnant woman expresses the desire for vaginal delivery, in many situations her will is not considered, because the speech of cesarean section is hegemonic in obstetrics. Thus, the pregnant woman who chooses vaginal delivery needs to use readings of the support of friends, family and other health professionals, as well as seek greater knowledge about her body, to support her decision in relationships with obstetricians.

Concomitantly with the results of this study, scientific production carried out in seven maternity hospitals in the Midwest region of Minas Gerais with 36 women, 10 obstetric nurses, and 14 obstetric physicians, indicated that it was possible to associate the choice of a cesarean section with health professionals. The authors indicate that women attributed the decision by cesarean section to the professionals' concern with maternal and child well-being and to the idea that technological intervention was necessary for the birth of a healthy baby. Even though women desired vaginal delivery, they believed that obstetricians would not perform a cesarean section if it were not necessary ${ }^{(18)}$.

Therefore, the care and bonds established between obstetricians and pregnant women enable relationships of trust, which matter so that women have the minimum of safety in the process of pregnancy and parturition. However, it is necessary to consider that, in these relationships, discourses and statements of power fields and specific knowledge are also present, in this case, the biomedical knowledge that situates the subjects and establishes positions of who can enunciate truths about pregnancy and parturition.

The discourse of risk is a good example, since, combined with intense surveillance, generates the need for tests, prescription of polyvitamins, healthy eating, physical activities, breast care and perinea, relaxation and breathing techniques, among other prescriptive care. Thus, such a speech produces a dressage of the pregnant body in the search for the prevention of obstetric complications. In this perspective, these interferences reinforce the idea that there are imperfections or malfunctions of the pregnant body, proper to the hegemonic biomedical field ${ }^{(19)}$. 
Furthermore, the guidelines and interventions provided during prenatal care or the process of parturition are forms of knowledge transmission that act directly on the female body, indicating the appropriate methods of conducting parturition and, thus, delimiting the contours of who is authorized, in fact, to conduct prenatal, childbirth, and postpartum procedures. One of the effects of these hierarchical knowledge-power relationships was recognized in the low acceptance by obstetricians regarding the birth route chosen by the postpartum women interviewed. Even with the presence of physiological changes, some postpartum women said they rejected the possibility of cesarean section until the end of the third trimester of pregnancy, showing that in the relationships established with the obstetricians, they exercised a certain freedom and resistance.

In this sense, Foucault ${ }^{(20)}$, when discussing the power-knowledge relationships, states that a certain degree of freedom is exercised in them. Otherwise, they should be called relationships of violence. The hierarchy that shapes the power diagram in which postpartum women and obstetricians are situated indicates that the biomedical argument leads women's conducts without resistance. Biomedical power-knowledge, as can be recognized here, leads the pregnant woman to consider her options.

The biomedical argument begins in the prenatal period, or even before this period, due to the trust and prestige deposited in the medical professional by the society, considering the social status of the knowledge of which he/she is the holder. This knowledge authorizes him/her as the holder of a technical-scientific knowledge responsible for the care of the mother and her child, thus ordering for and deciding the issues concerning the pregnant women's bodies. Another relevant aspect is the presence of the hospital as an institution that establishes differentiated positions of those who care and those who are cared for, contributing to the manufacture of submissive and disciplined bodies throughout the prenatal period and during childbirth ${ }^{(6)}$.

The conduction of the obstetrician in the choice of cesarean section can also be glimpsed in a research developed with women on co-management in the choice of delivery. The study revealed that when women made the choice by birth route individually, most opted for vaginal delivery. However, when the choice about the route of birth was of the obstetrician, most indicated cesarean section. In cases where it was possible to make the shared management of the decision, it was observed that the choice for cesarean section prevailed, however, in a lower percentage than when the decision was exclusive to the physician ${ }^{(4)}$.

In this study, one of the women also reported that the obstetrician questioned whether, in fact, she wanted a vaginal delivery, referring to fetus size and myoma as possible risk factors. It is noteworthy that some postpartum women, in addition to having sought knowledge, were health professionals and, still, there was a prevalence of the will of the obstetrician, unveiling the asymmetric relations of power between health professionals and pregnant women.

Furthermore, when the interviewees were questioned about the choice of a cesarean section, they assigned the decision to the obstetrician's arguments, evidencing a relationship of powerknowledge that authorizes them to do so. The discourses show that postpartum women attribute dominance of the field of knowledge of pregnancy and childbirth to the obstetrician. Still, it is possible to notice that the obstetrician's scientific knowledge is linked to, and contributes to, the exercise of a hierarchical power relationship, which affects the pregnant/parturient women's bodies.

Authors propose the reflection that obstetric hegemony focuses on childbirth based on the alienation of women about their own body and on the belief of the benefits of technology. In this sense, both present themselves as requirements to dodge childbirth as an event that involves uncontrollability and unpredictability. In this perspective, biomedical discourse also does not consider the will and knowledge of pregnant women ${ }^{(18,21)}$.

Moreover, the discourse of the obstetrician is marked by the woman's responsibility for the possibility of a negative outcome in vaginal delivery. This consideration contributes to the desire for not choosing vaginal delivery, opting for the cesarean section as the best decision to be made for the well-being of her baby.

In this sense, the literature is consistent with the findings of this study, indicating that the current discourse of hospital delivery refers to the obstetrician as the figure of resoluteness. With this, the process of parturition begins to be considered as pathology or problematic that needs to be solved with the performance of surgical intervention. Thus, the participation and spontaneity of women are placed in the background, to the detriment of the knowledge and efficacy of the prescriptions performed by obstetricians $s^{(2,22)}$.

Thus, in decisions about choices and rights about the body, women are responsible for themselves only in parts, because even if she prioritizes care, seeks information and guidance, she remains dependent on power and knowledge of the physician's authority, who will direct the best therapeutic options, prescribing the conducts to be performed ${ }^{(23)}$. According to Foucault ${ }^{(24)}$, there are authorized and legitimized voices, which produce effects of truths in society, therefore, no matter who utters the discourse, but the position that the subject occupies in the relationship of power-knowledge.

Therefore, it is considered that the obstetrician, holder of a legitimate scientific knowledge, occupies a privileged position in the relations of power-knowledge present in the context of the choice for cesarean section. This is a different place for women, because even if she has been oriented and sought information about vaginal delivery, she is submitted to the obstetrician who leads her choice regarding the route of birth.

\section{Study Limitations}

One limitation involves the fact that the study was conducted only with postpartum women from a single hospital, which does not allow generalizations regarding the theme addressed. Another limitation to be considered is the lack of feedback on the transcripts by the study participants, which could generate other nuances regarding the reasons and motives that led to the choice of cesarean section.

\section{Contributions to the Nursing and Health field}

The contributions to the health and nursing areas are in the possibility of looking at issues of choosing a cesarean section from another perspective, understanding that this decision intersects with plots, games of truth and power relationships, and is capable of producing subjects' ways of living, being, and 
behaving. Moreover, the study sought to promote problematization about health professionals and the power and knowledge relations established with women, allowing considering the position that each subject occupies in the truth regimes about the ways of birth and how this can influence to maintain a posture of submission of women to biomedical discourse.

\section{FINAL CONSIDERATIONS}

The study allowed recognizing that the choice of women for vaginal delivery is based on information and knowledge acquired in prenatal care, previous experience of parturition, influences of family, friends, the media and even agreement with the obstetrician. In addition, it was found that this decision is strongly determined by a field of knowledge and power relationships characteristic of the hegemonic biomedical field. Thus, regarding the aspects of knowledge and power relationships in the choice for a cesarean section, it was possible to infer that the obstetrician's discourse contributes to the conduct of pregnant women and their bodies.
Regarding cesarean sections, obstetricians lead pregnant women to change the birth route during prenatal care. This choice is linked to the circulation of "truths" regarding the cesarean section, establishing in this option not only obstetricians, but also pregnant women who change the method of giving birth.

\section{FUNDING}

Study conducted with funding from the Coordination of Higher Education Personnel (Coordenação Pessoal de Nível Superior - CAPES).

\section{SUPPLEMENTARY MATERIAL}

The article is part of the doctoral thesis entitled "Discourses between pregnant women and obstetricians in the choice of cesarean section: a Foucaultian analysis", available from: https:// wp.ufpel.edu.br/pgenfermagem/files/2019/01/sTESE-Ana-Paulade-Lima-Escobal.pdf

\section{REFERENCES}

1. Abreu LP, Lira Filho RL, Santana RL. Obstetric characteristics of pregnant women undergoing cesarean section, by the Robson Classification. Rev Enferm UERJ. 2019;27(e37858). https://doi.org/10.12957/reuerj.2019.37858

2. Caughey AB, Cahill AG, Guise JM, Rouse DJ. Safe prevention of the primary cesarean delivery. Am J Obstet Gynecol. 2014;210(3):179-93. https://doi.org/10.1016/j.ajog.2014.01.026

3. Russo JA. Is free choice for cesarean section really free? Physis (Rio J). 2019;29(3):1-4. https://doi.org/10.1590/S0103-73312019290301

4. Fernandes JA, Campos GWDS, Francisco PMSB. Profile of high-risk pregnant women and co-management of the decision on the route of birth delivery between doctor and pregnant woman. Saúde Debate. 2019;43(121):406-16. https://doi.org/10.1590/0103-1104201912109

5. Lara SRG, Magaton APFS, Cesar MBN, Gabrielloni MC, Barbieri M. Experience of women in labor with the use of flowers essences. Rev Pesqui: Cuid Fundam. 2020;12:162-8. https://doi.org/10.9789/2175-5361.rpcfo.v12.7178

6. Veleda AA, Gerhardt TE. From home to the third-dimension ultrasound: the paths in assistance of women assisted in the supplementary health sector of Porto Alegre - RS. Saúde Soc. 2018;27(3):929-43. https://doi.org/10.1590/s0104-12902018170427

7. Silva SD, Nakano AR, Bonan C. Routes of women submitted to cesariana in the public health care sector. Rev Pesqui: Cuid Fundam. 2021;13:8-16. https://doi.org/10.9789/2175-5361.rpcfo.v13.7114

8. Foucault M. Ditos e Escritos IV. Estratégia poder saber. Rio de Janeiro: Forense Universitária; 2010. 222p.

9. Foucault M. A arqueologia do saber. 8 ed. Rio de Janeiro: Forense Universitária; 2014. 124 p.

10. Ministério da Saúde (BR). Conselho Nacional de Saúde. Resolução n 466 de 12 de dezembro de 2012. Regulamenta a pesquisa envolvendo seres humanos. Diário Oficial da União: República Federativa do Brasil [Internet]. 2012 [cited 2020 Dec 5]; Seção 1:59 (col.3). D Available from: http://bvsms.saude.gov.br/bvs/saudelegis/cns/2013/res0466_12_12_2012.html

11. Meyer DE, Paraíso MA. Metodologias de pesquisas pós-críticas ou sobre como fazemos nossas investigações. In: Meyer DE, Paraíso MA. Pesquisas pós-críticas em educação. Belo Horizonte: Mazza Edições; 2012. 15-22 p.

12. O'Brien BC, Harris IB, Beckman TJ, Reed DA, Coo DA. Standards for reporting qualitative research: a synthesis of recommendations. Acad Med. 2014;89(9):1245-51. https://doi.org/10.1097/ACM.0000000000000388

13. Equator Network. Enhancing the quality and transparency of health research [Internet]. 2019 [cited 2020 Nov 20]. Available from: http:// www.equator-network.org/home

14. Minayo MCS. O desafio do conhecimento: pesquisa qualitativa em saúde. 14a ed. São Paulo: Hucitec; 2014. 604 p.

15. Robles B. The in-depth interview: a useful technique in the field of physical anthropology Cuicuilco [Internet]. 2003 [cited 2021 Feb 21];18(52):39-49. Available from: http://www.scielo.org.mx/pdf/cuicui/v18n52/v18n52a4.pdf

16. Paiva ACPC, Reis PV, Paiva LC, et al. From decision to cesarian: the woman perspective. Rev Enferm Cent Oeste Min. 2019;9:e3115. https:// doi.org/10.19175/recom.v9i0.3115

17. Martins APC, Jesus MVN, Prado Júnior PP, Passos CM. Aspects influencing women's decision making about the mode of delivery. Rev Baiana Enferm. 2018;32:e25025. https://doi.org/10.18471/rbe.v32.25025 
18. Oliveira VJ, Penna CMM. Every birth is a story: process of choosing the route of delivery. Rev Bras Enferm. 2018;71(Suppl 3):1228-36. https:// doi.org/10.1590/0034-7167-2016-0497

19. Ayres LFA, Henriques BD, Amorim WM. The cultural representation of "natural childbirth": the outlook on the pregnant body in the midtwentieth century. Ciênc Saúde Colet. 2018;23(11):3525-34. https://doi.org/10.1590/1413-812320182311.27812016

20. Foucault M. The hermeneutics of the subject. São Paulo: WMF Martins Fontes Ltda; $2011.674 \mathrm{p}$.

21. Arik RM, Parada CMGL, Tonete VLP, Sleutjes FCM. Perceptions and expectations of pregnant women about the type of birth. Rev Bras Enferm. 2019;72(Suppl 3):41-9. https://doi.org/10.1590/0034-7167-2017-0731

22. Kennedy DK, Kapodtsi E, Milipaak j, Kennedy DK, Mensima AR. Reasons for Women's Choice of Elective Caesarian Section in Duayaw Nkwanta Hospital. J Pregnancy. 2019.232743. https://doi.org/10.1155/2019/2320743

23. Cordeiro FR, Kruse MHL.The right to die and power over life: knowledge to govern the bodies. Texto Contexto Enferm. 2016;25(2):e3980014. https://doi.org/10.1590/0104-07072016003980014

24. Foucault M. Ordem do Discurso. São Paulo. Ed. Loyola; 2010. 79 p. 